\title{
Kualitas Hidup Pasien Kanker Rawat Jalan yang Menjalani Kemoterapi di RSUD Kota Yogyakarta
}

\author{
Quality of Life of Outpatient Cancer Patients Undergoing Chemotherapy in Regional Public Hospital \\ Yogyakarta
}

\author{
Ratna. R' ${ }^{1}$, Woro Supadmi ${ }^{*}$, Endang Yuniarti² \\ ${ }^{1}$ Program Pascasarjana Fakultas Farmasi, Universitas Ahmad Dahlan \\ 2 Rumah Sakit PKU Muhammadiyah Yogyakarta, STIKES Muhammadiyah Gombong \\ Corresponding author: Woro Supadmi; Email: wsupadmi@yahoo.com \\ Submitted:04-01-2021 Revised:22-01-2021 Accepted:25-01-2021
}

\begin{abstract}
ABSTRAK
Kualitas hidup merupakan kondisi dimana pasien memiliki kesejahteraan secara fisik, psikologis dan sosial serta mampu mengoptimalkan potensinya dalam kehidupan dan aktivitasnya sehari-hari. Jenis kanker dan kemoterapi yang diberikan dapat mempengaruhi kualitas hidup pasien kanker secara keseluruhan. Penelitian ini bertujuan untuk mengetahui gambaran kualitas hidup pasien kanker dengan menggunakan kuesioner EORTC QLQ-C30 dan menganalisis hubungan karakteristik demografi pasien, jenis kanker dan stadium kanker serta regimen kemoterapi dengan kualitas hidup pasien kanker. Penelitian ini merupakan penelitian observasional menggunakan desain cross sectional dengan subyek semua pasien kanker yang sedang menjalani kemoterapi di RSUD Kota Yogyakarta dan memenuhi kriteria inklusi selama bulan SeptemberOktober 2020. Data yang diperoleh dianalisis secara univariat menggunakan distribusi frekuensi dan dianalisis statistik dengan uji korelasi Spearman. Hasil penelitian menunjukkan skor rata-rata kualitas hidup pada skala status kesehatan global adalah $61,03 \pm 14,07$. Domain tertinggi pada skala fungsional adalah fungsi sosial dengan skor rata-rata 92,40 $\pm 17,14$ dan kehilangan nafsu makan merupakan domain tertinggi pada skala gejala dengan skor rata-rata $52,94 \pm 28,93$. Hasil analisis statistik menunjukkan bahwa terdapat hubungan yang signifikan antara karakteristik demografi pasien kanker (usia dan jenis kelamin) dengan kualitas hidup pada skala status kesehatan global $(\mathrm{p}<0,05)$, sedangkan untuk jenis kanker, stadium, regimen dan siklus kemoterapi tidak terdapat hubungan yang signifikan dengan kualitas hidup pada status kesehatan global $(p>0,05)$.

Kata kunci: EORTC QLQ-C30; kanker; kemoterapi; kualitas hidup
\end{abstract}

\section{ABSTRACT}

Quality of life is a condition where patients have physical, psychological and social well-being and are able to optimize their potential in their daily life and activities. The type of cancer and chemotherapy can affect the overall quality of life of cancer patients. This study aimed to describe the quality of life of cancer patients using the EORTC QLQ-C30 questionnaire and to analyze the relationship between patient demographic characteristics, cancer type, stage of cancer and chemotherapy regimens with the quality of life of cancer patients. This study was an observational study using a cross sectional design with all cancer patients as subjects who undergoing chemotherapy in Regional Public Hospital Yogyakarta and who met the inclusion criteria during September - October 2020. The data obtained were analyzed univariately using frequency distribution and statistical analysis using Spearman correlation tests. The results showed that the average score of quality of life on the global health status scale was $61.03 \pm 14.07$. The highest domain on the functional scale was social function with an average score of $92.40 \pm 17.14$ and loss of appetite was the highest domain on the symptom scale with an average score of $52.94 \pm 28.93$. The results of statistical analysis showed that there was a significant relationship between patient demographic characteristics (age and gender) with quality of life at global health status ( $p<0.05$ ), while for cancer type, stage of cancer, regimen and chemotherapy cycle there was not significant relationship with quality of life at global health status $(\mathrm{p}>0.05)$.

Keywords: EORTC QLQ-C30; cancer; chemotherapy; quality of life

\section{PENDAHULUAN}

Kanker merupakan suatu penyakit yang ditandai oleh siklus hidup atau pertumbuhan sel yang abnormal dan bersifat invasi dengan cara bermetastasis ke jaringan tubuh lainnya melalui pembuluh darah dan pembuluh getah bening hingga mengakibatkan kondisi yang serius dan kematian pada pasien (NCCN, 2019; Alldredge et al., 2013). Penderita kanker semakin meningkat seiring dengan bertambahnya populasi warga di seluruh dunia. Data GLOBOCAN tahun 2018 menunjukkan kasus kanker payudara, kanker serviks, kanker paru dan kolorektal merupakan kasus kanker yang 
paling banyak terjadi di Indonesia (WHO, 2019). Kualitas hidup pasien kanker merupakan gambaran fungsi fisik, psikologis dan sosial untuk melakukan aktivitas sehari-hari serta fungsi peran yang berdampak terhadap karier atau pekerjaan (Scherz et al., 2017). Kualitas hidup pasien kanker bergantung pada jenis kanker dan terapi yang diberikan, khususnya pada fungsi fisik dan kelelahan yang dialami pasien (Dąbrowska-Bender et al., 2017). Efek samping dari kemoterapi juga dapat berpengaruh terhadap menurunnya kualitas hidup terkait kesehatan pada pasien kanker, sehingga perlu diketahui pemilihan regimen kemoterapi yang sesuai dan tepat dalam meningkatkan efektifitas terapi pada pasien kanker (Ballatori \& Roila, 2003; Gatot et al., 2017).

Evaluasi kualitas hidup pasien dengan penyakit kronis semakin penting dalam penelitian dan pengobatan khususnya di bidang onkologi untuk pasien rawat jalan, rawat inap maupun rehabilitasi (Hinz et al., 2018). National Institute of Cancer dan Eropean Organization for Research and Treatment of Cancer (EORTC) telah mengembangkan penelitian tentang kualitas hidup pasien kanker dengan kuesioner EORTC QLQ-C30 dan telah digunakan dalam berbagai penelitian uji klinik (Kleijn et al., 2006).

Oleh karena itu, perlu dilakukan penelitian mengenai gambaran kualitas hidup pasien kanker yang menjalani kemoterapi dengan menggunakan kuesioner EORTC QLQC30 di RSUD Kota Yogyakarta. Kuesioner EORTC QLQ-C30 telah diterjemahkan dan divalidasi ke dalam bahasa Indonesia untuk digunakan dalam penelitian pasien kanker di Indonesia. Kuesioner ini terdiri dari 30 item pertanyaan meliputi 5 skala fungsional (fungsi fisik, fungsi peran, fungsi emosional, fungsi kognitif, dan fungsi sosial), 3 skala gejala (kelelahan, nyeri, dan mual atau muntah), 1 skala status kesehatan global atau kualitas hidup secara umum, dan 6 item tunggal untuk berbagai gejala (sesak nafas, insomnia, kehilangan nafsu makan, konstipasi, diare dan dampak kesulitan keuangan) (Perwitasari et al., 2011).

\section{METODOLOGI}

Penelitian ini merupakan penelitian observasional dengan rancangan Cross Sectional. Pengumpulan data dilakukan secara prospektif selama periode bulan
September - Oktober 2020 di RSUD Kota Yogyakarta. Penelitian ini telah mendapat persetujuan etik dari Komite Etik Penelitian Kesehatan RSUD Kota Yogyakarta dengan Nomor 36/KEP/RSUD/VIII/2020.

Teknik pengambilan sampel dilakukan dengan metode purposive sampling yaitu memilih semua pasien kanker yang menjalani kemoterapi selama periode penelitian di RSUD Kota Yogyakarta. Kriteria inklusi meliputi semua pasien baik laki-laki maupun perempuan yang telah terdiagnosis kanker, pasien berusia $\geq$ 18 tahun, pasien sedang menjalani kemoterapi di RSUD Kota Yogyakarta, dapat berkomunikasi dengan baik dan kooperatif serta bersedia menjadi subjek penelitian dengan mengisi Informed Consent. Kriteria ekslusi meliputi pasien yang mengalami komplikasi penyakit kronis lainnya (kardiovaskular, diabetes mellitus, gangguan fungsi ginjal dan gangguan fungsi hati). Pasien yang telah menyatakan bersedia untuk ikut menjadi subjek penelitian, selanjutnya diberikan penjelasan mengenai cara pengisian kuesioner EORTC QLQ-C30 dengan didampingi oleh peneliti.

Pengukuran kualitas hidup dengan menggunakan hasil pengisian kuesioner EORTC QLQ-C30 terdiri dari dua tahap, yaitu tahap pertama dengan menghitung raw score setiap skala dengan menggunakan rumus berikut:

$$
\text { Raw score: } \mathrm{RS}=(\mathrm{I} 1+\mathrm{I} 2+\mathrm{I} 3+\ldots \ldots . \mathrm{In}) / \mathrm{n}
$$

Keterangan: $\mathrm{I}=$ nilai tiap item pertanyaan, dan $\mathrm{n}=$ jumlah dari keseluruhan pertanyaan

Tahap kedua yaitu tahap transformasi linear dengan melakukan standarisasi raw score sehingga diperoleh rentang skor antara 1-100 dengan menggunakan rumus transformasi linier berikut:

Skala fungsional: $\mathrm{S}=\{1-[(\mathrm{RS}-1)] /$ range $\} \times 100$

Skala Gejala: $S=\{(\mathrm{RS}-1) /$ range $\} \times 100$

Status Kesehatan Global: $\mathrm{S}=\{(\mathrm{RS}-1) /$ range $\mathrm{x} \times 100$

Keterangan: $\mathrm{S}=$ Skor dan RS = Raw score

Skor untuk semua item antara 1-4, maka range $=3$, kecuali pada item yang berkontribusi terhadap status kesehatan global (QoL), yaitu pertanyaan dengan 7 poin, maka range $=6$.

Prinsip perhitungan semua skala atau domain adalah sama untuk semua kasus kanker. Pada skala fungsional, semakin tinggi skor menunjukkan level fungsional yang baik. 
Skor yang tinggi pada status kesehatan global menunjukkan kualitas hidup yang baik dan skor yang tinggi pada skala gejala menunjukkan tingginya masalah pada pasien kanker atau gejala yang buruk (Bottomley, 2002). Data yang diperoleh dianalisis statistik dengan uji korelasi Spearman untuk mengetahui hubungan karakteristik demografi pasien, jenis kanker, stadium kanker dan regimen kemoterapi dengan kualitas hidup pasien kanker.

\section{HASIL DAN PEMBAHASAN Karakteristik Pasien}

Hasil penelitian diperoleh jumlah pasien yang bersedia ikut serta dalam penelitian dan memenuhi kriteria inklusi selama periode bulan September-Oktober 2020 sebanyak 68 orang. Gambaran karakteristik data pasien kanker di RSUD Kota Yogyakarta meliputi usia, jenis kelamin, jenis kanker, stadium kanker, regimen dan siklus kemoterapi (tabel I).

Tabel I menunjukkan distribusi pasien kanker berdasarkan kelompok usia yang paling banyak terdiagnosis kanker adalah kelompok usia lansia (46-65 tahun) dengan jumlah 34 orang $(50,0 \%)$. Kelompok usia dewasa awal (2635 tahun) merupakan yang paling sedikit dengan jumlah 4 orang $(5,9 \%)$. Hal ini sejalan dengan hasil penelitian di RSU Prof.DR.W.Z. Johannes Kupang yaitu pada kategori lansia sebanyak 58 orang $(56,3 \%)$ sedangkan paling sedikit adalah manula dan remaja masingmasing sebanyak 2 orang $(1,9 \%$ ) (Toulasik et al., 2019). Insiden kanker meningkat sejalan dengan pertambahan usia yang penyebabnya mungkin karena zat iritan karsinogenik menimbulkan transformasi, perubahan ganas dan timbulnya tumor memerlukan proses yang relatif panjang serta imunitas tubuh yang menurun khususnya pada usia lansia (Desen, 2013).

Pasien kanker dengan jenis kelamin perempuan merupakan pasien yang paling banyak terdiagnosis kanker yaitu sebanyak 60 orang $(88,2 \%)$ dan pasien kanker dengan jenis kelamin laki-laki sebanyak 8 orang $(11,8 \%)$. Gaya hidup tidak sehat, konsumsi makanan yang berlemak dan produksi hormon estrogen dan progesteron yang berlebihan dalam tubuh diperkirakan dapat memicu terjadinya kanker pada perempuan (C.Maringka et al., 2020).
Kanker payudara merupakan jenis kanker terbanyak berdasarkan hasil diagnosa pada pasien kankeryang menjalani kemoterapi yaitu sebanyak 50 orang $(73,5 \%)$, kemudian diikuti pasien dengan Limfoma Non Hodgkin sebanyak 6 orang $(8,8 \%)$. Jenis kanker yang paling sedikit terdiagnosa adalah kanker paru, kanker serviks, kanker ginjal dan kanker buli masing-masing dengan jumlah 1 orang $(1,5 \%)$.

Distribusi stadium pasien kanker yang paling banyak adalah stadium III dengan jumlah 22 orang $(32,4 \%)$. Pada umumnya pasien kanker terdeteksi pada stadium lanjut (III-IV) dengan keluhan yang sudah parah (Nisfulaili, 2017). Pasien kanker akan mencari pengobatan tradisional terlebih dahulu sebelum memulai perawatan di rumah sakit karena adanya persepsi negatif, hambatan keuangan dan pemahaman yang buruk tentang penyakit kanker (Ganesh et al., 2016). Perkembangan risiko kanker mulai terjadi setelah umur 25 tahun dan meningkat pada wanita usia 35-50 tahun (Tunas et al., 2016).

Pasien kanker yang mendapatkan regimen kemoterapi kombinasi golongan Taxan (Docetaxel/Paclitaxel) $\quad+\quad$ Epirubicin +Carboplatin (TEC) merupakan yang paling banyak dengan jumlah 34 orang $(50,0 \%)$ dan diikuti dengan regimen kombinasi golongan Taxan (Docetaxel/ Paclitaxel) + Doxorubicin+Cisplatin (TAC) dengan jumlah 10 orang $(14,7 \%)$. Pasien dengan kanker payudara merupakan kasus yang paling banyak menerima regimen kemoterapi kombinasi TEC dan TAC sesuai dengan protokol kemoterapi di RSUD Kota Yogyakarta. Pemilihan regimen kemoterapi berdasarkan National Comprehensive Cancer Network (NCCN) guidelines dan Panduan Penatalaksaan Kanker yang diterbitkan oleh Komite Penanggulangan Kanker Nasional Kementerian Kesehatan Republik Indonesia.

Pasien kanker yang menjalani siklus kemoterapi (1-3) merupakan yang paling banyak yaitu dengan jumlah 32 orang $(47,1 \%)$. Pasien kanker yang menjalani siklus kemoterapi (4-6) sebanyak 16 orang $(23,5 \%)$ dan pasien kanker yang menjalani siklus kemoterapi $(\geq 7)$ sebanyak 20 orang $(29,4 \%)$.

\section{Kualitas Hidup Pasien Kanker}

Pengukuran kualitas hidup pada pasien kanker di RSUD Kota Yogyakarta menggunakan 
Kualitas Hidup Pasien Kanker Rawat Jalan yang Menjalani Kemoterapi di

Tabel I. Karakteristik Data Pasien yang Menjalani Kemoterapi

\begin{tabular}{|c|c|c|}
\hline Karakteristik Pasien & Frekuensi $(n=68)$ & Persentase (\%) \\
\hline \multicolumn{3}{|l|}{ Usia } \\
\hline 18-25 tahun & 0 & 0,0 \\
\hline 26-35 tahun & 4 & 5,9 \\
\hline 36-45 tahun & 14 & 20,6 \\
\hline 46-65 tahun & 34 & 50,0 \\
\hline$>65$ tahun & 16 & 23,5 \\
\hline \multicolumn{3}{|l|}{ Jenis Kelamin } \\
\hline Laki-laki & 8 & 11,8 \\
\hline Perempuan & 60 & 88,2 \\
\hline \multicolumn{3}{|l|}{ Jenis Kanker } \\
\hline Kanker Payudara & 50 & 73,5 \\
\hline Limfoma Non Hodgkin & 6 & 8,8 \\
\hline Kanker Prostat & 2 & 2,9 \\
\hline Kanker Kulit & 3 & 4,4 \\
\hline Kanker Paru & 1 & 1,5 \\
\hline Kanker Serviks & 1 & 1,5 \\
\hline Kanker Ginjal & 1 & 1,5 \\
\hline Kanker Buli & 1 & 1,5 \\
\hline Sarkoma Jaringan Lunak & 3 & 4,4 \\
\hline \multicolumn{3}{|l|}{ Stadium Kanker } \\
\hline I & 16 & 23,5 \\
\hline II & 17 & 25,0 \\
\hline III & 22 & 32,4 \\
\hline IV & 13 & 19,1 \\
\hline \multicolumn{3}{|l|}{ Regimen Kemoterapi } \\
\hline $\mathrm{T}$ & 6 & 8,8 \\
\hline TC & 1 & 1,5 \\
\hline TE & 5 & 7,4 \\
\hline DC & 1 & 1,5 \\
\hline $\mathrm{AC}$ & 1 & 1,5 \\
\hline TEC & 34 & 50,0 \\
\hline TAC & 10 & 14,7 \\
\hline TCF & 2 & 2,9 \\
\hline TAV & 1 & 1,5 \\
\hline TEV & 7 & 10,3 \\
\hline \multicolumn{3}{|l|}{ Siklus Kemoterapi } \\
\hline $1-3$ & 32 & 47,1 \\
\hline $4-6$ & 16 & 23,5 \\
\hline$>7$ & 20 & 29,4 \\
\hline
\end{tabular}

Keterangan: $\mathrm{T}=$ Golongan Taxan (Docetaxel/Paclitaxel), TC (Paclitaxel+Carboplatin); TE (Taxan+Epirubicin); DC (Docetaxel+Cisplatin); AC (Doxorubicin+Cyclophosphamide); TEC (Taxan+Epirubicin+Carboplatin); $\quad$ TAC $\quad$ (Taxan+Doxorubicin+Cisplatin); $\quad$ TCF (Paclitaxel+Carboplatin+5-FluoroUracil); TAV (Paclitaxel+Doxorubicin+Vincristin); TEV (Paclitaxel+Epirubicin+Vincristin).

kuesioner EORTC QLQ-C30 yang diadopsi dari Translation and Validation of EORTC QLQ-C3O Scoring Manual version 3.0 into Indonesian Version untuk pasien kanker di Indonesia oleh
Perwitasari et al (2011). Gambaran kualitas hidup pasien kanker berdasarkan penilaian atau skor jawaban kuesioner EORTC QLQ-C30 terlihat pada tabel II. 
Tabel II. Kualitas Hidup Pasien Kanker

\begin{tabular}{lc}
\hline Domain & Rata-rata \pm SD \\
\hline Skala status Kesehatan global & \\
Kualitas Hidup & $61,03 \pm 14,07$ \\
Rata-rata \pm SD & $61,03 \pm 14,07$ \\
Skala Fungsional & \\
Fungsi fisik & $80,10 \pm 24,88$ \\
Fungsi peran & $72,06 \pm 29,29$ \\
Fungsi emosional & $90,32 \pm 13,32$ \\
Fungsi Kognitif & $90,69 \pm 16,88$ \\
Fungsi sosial & $92,40 \pm 17,14$ \\
Rata - rata \pm SD & $85,11 \pm 8,76$ \\
Skala Gejala & \\
Kelelahan & $48,86 \pm 28,09$ \\
Mual dan Muntah & $31,62 \pm 24,29$ \\
Nyeri & $28,43 \pm 26,40$ \\
Sesak Nafas & $3,92 \pm 15,80$ \\
Insomnia & $28,43 \pm 33,22$ \\
Kehilangan nafsu makan & $52,94 \pm 28,93$ \\
Konstipasi & $20,10 \pm 26,48$ \\
Diare & $5,88 \pm 18,16$ \\
Hambatan Keuangan & $20,10 \pm 22,41$ \\
Rata-rata \pm SD & $26,70 \pm 16,77$ \\
\hline
\end{tabular}

Tabel II menunjukkan skala status kesehatan global pasien kanker dengan skor rata-rata kualitas hidup (QoL) 61,03 $\pm 14,07$. Pertanyaan yang menggambarkan status kesehatan global berhubungan dengan penilaian pasien terhadap kondisi kesehatan dan kualitas hidupnya secara keseluruhan setelah menjalani kemoterapi di RSUD Kota Yogyakarta.

Pada skala fungsional diperoleh skor rata-rata adalah $85,11 \pm 8,76$. Domain tertinggi pada skala fungsional adalah fungsi sosial dengan skor rata-rata $92,40 \pm 17,14$. Pada fungsi kognitif dan fungsi emosional diperoleh skor rata-rata $90,69 \pm 16,88$ dan $90,32 \pm 13,32$. Pasien kanker yang menjalani terapi membutuhkan dukungan emosional dan sosial untuk mengatasi efek psikologi dan psikososial selama proses diagnosis dan pengobatan (Butow et al., 2014; Sanders et al., 2014). Dukungan tersebut dapat diperoleh dari keluarga, lingkungan dan komunitas sesama pasien kanker, sehingga pasien kanker tetap merasa optimis selama menjalani terapi (Putri, 2017).

Fungsi fisik dan fungsi peran merupakan domain terendah pada skala fungsional yaitu masing-masing dengan skor rata-rata $80,10 \pm 24,88$ dan $72,06 \pm 29,29$. Hal ini sejalan dengan hasil penelitian Almutairi et al (2016) pada 145 pasien kanker payudara di Arab Saudi menunjukkan fungsi fisik merupakan skor ratarata terendah pada skala fungsional yaitu $62,9 \pm 24,6$. Kondisi medis dan efek samping kemoterapi dapat mempengaruhi fungsi fisik dan fungsi peran pada pasien kanker (Agustini et al., 2015). Pasien tidak dapat menjalankan perannya secara maksimal dalam melakukan aktivitas sehari-hari karena harus beristirahat total setelah menjalani kemoterapi (Wulandari, 2017). Hasil penelitian Tachi et al (2015) di RS Gifu Municipal Jepang menunjukkan penurunan kualitas hidup pasien kanker payudara pada subskala aktivitas dan kondisi fisik setelah menjalani kemoterapi.

Pada skala gejala diperoleh skor rata-rata adalah $26,70 \pm 16,77$. Kehilangan nafsu makan merupakan skor rata-rata tertinggi pada skala gejala dengan skor $52,94 \pm 28,93$. Skor rata- rata pada skala kelelahan adalah $48,86 \pm 28,09$, kemudian diikuti gejala mual dan muntah dengan skor rata-rata $31,62 \pm 24,29$. Sesak nafas merupakan skala gejala terendah dengan skor rata-rata 3,92 $\pm 15,80$ dikarenakan jarang terjadi gejala sesak nafas pada pasien kanker setelah menjalani kemoterapi. 
Tabel III. Kualitas Hidup pada status kesehatan global berdasarkan Karakteristik Pasien

\begin{tabular}{lcr}
\hline Karakteristik Pasien & Frekuensi (n = 68) & QoL (Rata-rata \pm SD) \\
\hline Usia & 0 & 0,0 \\
18-25 tahun & 4 & $72,92 \pm 7,97$ \\
$26-35$ tahun & 14 & $67,86 \pm 13,81$ \\
$36-45$ tahun & 34 & $60,54 \pm 13,34$ \\
$46-65$ tahun & 16 & $53,12 \pm 12,86$ \\
>65 tahun & & \\
Jenis Kelamin & 8 & $69,79 \pm 9,89$ \\
Laki-laki & 60 & $59,86 \pm 14,19$ \\
Perempuan & & \\
Jenis Kanker & 50 & $60,67 \pm 13,68$ \\
Kanker Payudara & 6 & $62,50 \pm 16,46$ \\
Limfoma Non Hodgkin & 2 & $70,83 \pm 5,89$ \\
Kanker Prostat & 3 & $52,78 \pm 19,24$ \\
Kanker Kulit & 3 & $77,78 \pm 4,81$ \\
Sarkoma Jaringan Lunak & 4 & $52,08 \pm 10,49$ \\
Kanker lain-lain & & \\
(Paru,Ginjal,Serviks,Buli) & & \\
Stadium & 16 & $64,06 \pm 13,16$ \\
I & 17 & $61,76 \pm 13,19$ \\
II & 22 & $63,26 \pm 13,52$ \\
III & 13 & $52,56 \pm 15,36$ \\
RV & & \\
Tunggal & 62 & $62,50 \pm 15,59$ \\
Kombinasi & & $60,89 \pm 14,04$ \\
Siklus & & \\
1-3 & & $63,28 \pm 15,24$ \\
4-6 7 & 32 & $57,81 \pm 12,35$ \\
7 & 16 & $60,00 \pm 13,41$ \\
\hline
\end{tabular}

Hasil penelitian terhadap pasien kanker ginekolog di RSUP Dr. Sardjito Yogyakarta menggunakan terapi cisplatin dengan dosis 50 $\mathrm{mg} / \mathrm{m}^{2}$ atau lebih sebagai monoterapi atau kombinasi, sebagian besar mengalami gejala seperti kelelahan, mual muntah dan kehilangan nafsu makan meskipun telah menggunakan profilaksis antiemetik. Gejala tersebut dapat memberikan dampak negatif terhadap kualitas hidup pasien kanker (Perwitasari et al., 2012).

Pengobatan kanker dengan kemoterapi khususnya pada penggunaan obat sitotoksik seperti cisplatin, karboplatin, paklitaksel, siklofosfamid dan epirubisin berpotensi lebih tinggi menyebabkan resiko emesis ( $>90 \%$ ) pada pasien (Ballatori \& Roila, 2003; Juwita et al., 2019). Gejala mual muntah dapat menyebabkan nafsu makan dan status gizi berkurang, kelelahan (fatigue), dehidrasi serta gangguan elektrolit pada pasien sehingga pasien harus beristirahat total dan tidak dapat melakukan aktivitas yang membutuhkan banyak energi (Tunas et al., 2016). Hasil penelitian Kirca \& Kutluturkan (2018) pada pasien kanker payudara yang menggunakan obat kemoterapi golongan Taxan di RS Universitas Turki, menunjukkan skor rata-rata tertinggi pada skala gejala nyeri $(42.01 \pm 15.37)$ dan fatigue (41.46 \pm 16.32$)$.

\section{Hubungan Karakteristik Pasien dengan Kualitas Hidup}

Faktor utama dalam memperparah gejala yang dialami pasien dan sangat mempengaruhi kualitas hidup secara keseluruhan adalah efek samping dari pemberian kemoterapi yang sangat bervariasi tergantung dari jenis, dosis pengobatan, status kesehatan dan stadium kanker. Karakteristik sosial demografi (usia, jenis kelamin, status pekerjaan dan tingkat 
Ratna. R, et al

Tabel IV. Hubungan Karakteristik Pasien dengan Kualitas Hidup pada Status Kesehatan Global

\begin{tabular}{lcc}
\hline \multirow{2}{*}{ Karakteristik Pasien } & \multicolumn{3}{c}{ Kualitas Hidup } \\
\cline { 2 - 3 } & $\mathbf{r}$ & $\boldsymbol{p}$-value \\
\hline Usia & $-0,396$ & $0,001^{*}$ \\
Jenis Kelamin & $-0,243$ & $0,046^{*}$ \\
Jenis Kanker & 0,052 & 0,672 \\
Stadium Kanker & $-0,206$ & 0,091 \\
Regimen Kemoterapi & $-0,051$ & 0,679 \\
Siklus Kemoterapi & $-0,066$ & 0,593 \\
\hline
\end{tabular}

Keterangan : $\left({ }^{*}\right)$ p-value $=<0,05$

pendidikan) juga berpengaruh pada kualitas hidup pasien kanker (Ballatori \& Roila, 2003; Dąbrowska-Bender et al., 2017; Scherz et al., 2017).

Pada Tabel IV, hasil analisis statistik menunjukkan bahwa terdapat hubungan usia pasien kanker dengan kualitas hidup pada skala status kesehatan global $(p=0,001)$ dengan koefisien korelasi Spearman ( $r=-0,396)$ menunjukkan korelasi negatif yaitu dengan bertambahnya usia dapat mempengaruhi penurunan kualitas hidup pasien kanker. Hasil penelitian ini sejalan dengan penelitian Ganesh et al (2016) pada pasien kanker payudara di Malaysia yang menunjukkan bahwa usia berpengaruh signifikan terhadap kualitas hidup pasien terutama pada skala gejala.

Jenis kelamin pasien kanker juga berhubungan secara signifikan dengan kualitas hidup pada skala status kesehatan global $(\mathrm{p}=0,046)$ dengan koefisien korelasi Spearman $(\mathrm{r}=-0,243)$ menunjukkan korelasi negatif yaitu pasien kanker wanita mengalami penurunan kualitas hidup (tabel III). Hasil penelitian ini sejalan dengan penelitian Chang et al (2015) pada pasien kanker paru pasca lobektomi di RS Taipei Taiwan menunjukkan kualitas hidup pasien kanker laki-laki dan perempuan memiliki perbedaan yang signifikan khususnya pada fungsi fisik, fungsi emosional dan fungsi kognitif.

Tabel IV menunjukkan bahwa tidak terdapat hubungan yang signifikan jenis kanker $(\mathrm{p}=0,672)$ dan stadium kanker $(\mathrm{p}=0,091)$ dengan kualitas hidup pada skala status kesehatan global. Hasil penelitian ini sejalan dengan penelitian Putri (2017) pada pasien kanker serviks dan kanker ovarium yang sedang menjalani terapi di RS Kanker Dharmais dan RSPAD Gatot Soebroto, menunjukkan bahwa jenis kanker tidak berhubungan dengan kualitas hidup pasien kanker ginekologi ( $p>0,05)$. Hasil penelitian Wulandari (2017) menunjukkan bahwa kualitas hidup pasien secara umum pada pasien kanker serviks dan kanker ovarium di RSUP Dr.Sardjito tidak terdapat perbedaan yang bermakna $(p>0,05)$.

Pemilihan regimen baik monoterapi ataupun kombinasi bertujuan untuk menghasilkan efikasi yang maksimal, mengurangi efek toksisitas obat dan mencegah resistensi obat antikanker (NCCN, 2019). Terjadinya efek samping kemoterapi pada saat pengobatan dapat berpengaruh terhadap kualitas hidup pasien kanker (NCI, 2019).

Tabel III menunjukkan kualitas hidup pada pemberian regimen kombinasi lebih rendah dibandingkan dengan regimen tunggal. Akan tetapi, hasil analisis statistik pada penelitian ini menunjukkan bahwa tidak terdapat hubungan jenis regimen tunggal dan kombinasi dengan kualitas hidup pada skala status kesehatan global $(\mathrm{p}=0,679)$. Hasil penelitian Juwita et al (2018) di RSUP Dr. M. Djamil Padang juga menunjukkan bahwa tidak terdapat pengaruh bermakna jenis kemoterapi tunggal dan kombinasi terhadap nilai kualitas hidup pasien kanker payudara $(\mathrm{p}>0,05)$.

Hasil uji statistik pada siklus kemoterapi juga menunjukkan bahwa tidak terdapat hubungan dengan kualitas hidup pada skala status kesehatan global $(p=0,593)$. Hal ini sejalan dengan hasil penelitian Agustini et al (2015) pada pasien kanker payudara dengan terapi kombinasi Florourasil (5FU), Doxorubicin dan Cyclofosfamide (FAC) di RSUP Hasan Sadikin yang menunjukkan bahwa tidak terdapat perbedaan kualitas hidup pada dimensi kesehatan umum yang signifikan antara siklus ke-1 sampai dengan siklus ke-5 berdasarkan uji t-test (nilai $\mathrm{p}>0,05$ ) karena 
sebelumnya pasien telah diberikan informasi mengenai efek samping yang akan terjadi setelah menjalani kemoterapi.

\section{KESIMPULAN}

Hasil penelitian menunjukkan kualitas hidup pasien kanker yang menjalani kemoterapi di RSUD Kota Yogyakarta dalam kategori baik dengan skor rata-rata skala fungsional yang tinggi dan skor rata-rata skala gejala yang rendah.

\section{UCAPAN TERIMA KASIH}

Penulis mengucapkan terima kasih kepada Direktur RSUD Kota Yogyakarta yang telah memberikan izin kepada peneliti untuk melakukan penelitian dan terima kasih kepada dosen pembimbing yang telah memberikan bimbingan dalam menyelesaikan penelitian ini.

\section{DAFTAR PUSTAKA}

Agustini, D. D., Surahman, E., \& Abdulah, R. 2015. Quality of Life Patients with Breast Cancer Therapy Combination Fluorouracil, Doxorubicin, and Cyclofosfamide. Indonesian Journal of Clinical Pharmacy, 4(3), 175-185.

Alldredge, B. K., Corelli, R. L., Ernst, M. E., \& Guglielmo, B. J. 2013. Koda-Kimble \& Young's: Applied Therapeutic, The clinical Use of Drugs (10th Edition). In Lippincott Williams \& Wilkins.

Almutairi, K. M., Mansour, E. A., \& Vinluan, J. M. 2016. A cross-sectional assessment of quality of life of breast cancer patients in Saudi Arabia. Public Health, 136, 117125.

Ballatori, E., \& Roila, F. 2003. Impact of nausea and vomiting on quality of life in cancer patients during chemotherapy. Health and Quality of Life Outcomes, 1, 1-11.

Bottomley, A. 2002. The Cancer Patient and Quality of Life. The Oncologist, 7(2), 120125.

Butow, P. N., Price, M. A., Bell, M. L., Webb, P. M., Defazio, A., \& Friedlander, M. 2014. Caring for women with ovarian cancer in the last year of life: A longitudinal study of caregiver quality of life, distress and unmet needs. Gynecologic Oncology, 132(3), 690-697.

C. Maringka, P., I. Wiyono, W., \& Antasionasti, I. 2020. Penilaian Kualitas Hidup Pada Pasien Kanker di Ruangan Irina Delima
RSUP Prof. Dr. R. D. Kandou Manado. Jurnal Biomedik, 12(2), 139-143.

Chang, N. W., Lin, K. C., Hsu, W. H., Lee, S. C., Chan, J. Y. H., \& Wang, K. Y. 2015. The effect of gender on health-related quality of life and related factors in post-lobectomy lung-cancer patients. European Journal of Oncology Nursing, 19(3), 292-300.

Dąbrowska-Bender, M., Słoniewski, R., Religioni, U., Juszczyk, G., Słoniewska, A., \& Staniszewska, A. 2017. Analysis of Quality of Life Subjective Perception by Patients Treated for Prostate Cancer with the EORTC QLQ-C30 Questionnaire and QLQPR25 Module. Journal of Cancer Education, 32(3), 509-515.

Desen, W. 2013. Kemoterapi Tumor Ganas Buku Ajar Onkologi Klinis (II). Balai Penerbit FKUI.

Ganesh, S., Lye, M. S., \& Lau, F. N. 2016. Quality of life among breast cancer patients in Malaysia. Asian Pacific Journal of Cancer Prevention, 17(4), 1677-1684.

Gatot, D., Handayani, S., Lubis, H. S., Suhartono, \& Tawarta. 2017. peranan kemoterapi pada kanker. Divisi Hematologi Onkologi Medik Departemen Ilmu Penyakit Dalam, Medan, 1-12.

Hinz, A., Weis, J., Faller, H., Brähler, E., Härter, M., Keller, M., Schulz, H., Wegscheider, K., Koch, U., Geue, K., Götze, H., \& Mehnert, A. 2018. Quality of life in cancer patients-a comparison of inpatient, outpatient, and rehabilitation settings. Supportive Care in Cancer, 26(10),3533-3541.

Juwita, D. A., Almahdy, A., \& Afdila, R. 2019. Penilaian Kualitas Hidup Terkait Kesehatan Pasien Kanker Payudara di RSUP dr. M. Djamil Padang, Indonesia. Jurnal Ilmu Kefarmasian Indonesia, 17(1), 114.

Kirca, K., \& Kutluturkan, S. 2018. Symptoms Experience and Quality of Life in The Patients with Breast Cancer Receiving The Taxane Class of Drugs. European Journal of Breast Health, 148-155.

Kleijn, W. C., Ogoshi, K., Yamaoka, K., Shigehisa, T., Takeda, Y., Creutzberg, C. L., Nortier, J. W. R., \& Kaptein, A. A. 2006. Conceptual equivalence and health-related quality of life: An exploratory study in Japanese and Dutch cancer patients. Quality of Life Research, 15(6), 1091-1101.

NCCN. 2019. NCCN Clinical Practice guidelines in 
Oncology. National Comprehensive Cancer Network.

NCI. 2019. In NCI. National Cancer Instutute, USA.gov.

Nisfulaili, I. 2017. Gambaran Kualitas Hidup pada Pasien Kanker di RSUP H. Adam Malik. Fakultas Kedokteran, Universitas Sumatera Utara.

Perwitasari, D. A., Atthobari, J., Dwiprahasto, I., Hakimi, M., Gelderblom, H., Putter, H., Nortier, J. W. R., Guchelaar, H., \& Kaptein, A. A. 2011. Translation and Validation of EORTC QLQ-C30 into Indonesian Version for Cancer Patients in Indonesia. Japanese Journal of Clinical Oncology, 41(January), 519-529.

Perwitasari, D. A., Atthobari, J., Mustofa, M., Dwiprahasto, I., Hakimi, M., Gelderblom, H., Putter, H., Nortier, J. W. R., Guchelaar, H. J., \& Kaptein, A. A. 2012. Impact of chemotherapy-induced nausea and vomiting on quality of life in Indonesian patients with gynecologic cancer. International Journal of Gynecological Cancer, 22(1), 139-145.

Putri, R. H. 2017. Kualitas Hidup Pasien Kanker Ginekologi yang Menjalani Terapi. Jurnal Aisyah : Jurnal Ilmu Kesehatan, 2(1), 6974.

Sanders, J. B., Loftin, A., Seda, J. S., \& Ehlenbeck, C. 2014. Psychosocial distress affecting patients with ductal carcinoma in situ compared to patients with early invasive breast cancer. Clinical Journal of Oncology
Nursing, 18(6), 684-688.

Scherz, N., Bachmann-Mettler, I., Chmiel, C., Senn, 0., Boss, N., Bardheci, K., \& Rosemann, T. 2017. Case management to increase quality of life after cancer treatment: A randomized controlled trial. BMC Cancer, 17(1), 1-8.

Tachi, T., Teramachi, H., Tanaka, K., Asano, S., Osawa, T., Kawashima, A., Yasuda, M., Mizui, T., Nakada, T., Noguchi, Y., Tsuchiya, T., \& Goto, C. 2015. The impact of outpatient chemotherapy-related adverse events on the quality of life of breast cancer patients. PLoS ONE, 10(4), $1-15$.

Toulasik, N., Kusumaningrum, T., \& Pradanie, R. 2019. Analisis Faktor yang berhubungan dengan Kualitas Hidup Wanita Penderita Kanker. Pediomaternal Nursing Journal, 5(1).

Tunas, I. K., Yowani, S. C., Indrayathi, P. A., Noviyani, R., \& Budiana, I. N. G. 2016. The Assessment Quality of Life for Patients with Cervical Cancer Using Chemotherapy Paclitaxel-Carboplatin in Sanglah. Indonesian Journal of Clinical Pharmacy, 5(1), 35-46.

WHO. 2019. Indonesia Source GLOBOCAN 2018. International Agency for Research on Cancer, 256, 1-2. http://gco.iarc.fr/

Wulandari, M. R. S. 2017. Komparasi Kualitas Hidup Wanita Penderita Kanker Serviks Dan Kanker Ovarium Berdasarkan Siklus Kemoterapi., 1(1), 199-205. 